\title{
Due Process in Undesirable Discharge Proceedings
}

It is generally agreed that a discharge "under other than honorable conditions" imposes serious consequences on a serviceman. Unlike an honorable or a general discharge, an undesirable, bad-conduct, or dishonorable discharge may deprive a serviceman of nearly all veterans' benefits, ${ }^{2}$ and inflict a stigma that reduces his civilian employment potential. ${ }^{3}$ The civilian disabilities flow from the widespread knowledge that the Armed Forces grant other than honorable discharges only to willfully incompatible personnel-from repeated petty offenders, who receive undesirable discharges, to court-martialled felons, who receive dishonorable discharges. ${ }^{4}$

A serviceman faced with an other than honorable discharge has much at stake and, therefore, a strong interest in procedural safeguards. This interest conflicts, however, with important military interests. The Armed Forces need a swift and economical procedure for separating from the service those who will not perform satisfactorily. The services also require a means of penalizing offenders by imposing disabilities that affect both their veterans' benefits and their civilian careers. ${ }^{5}$

Where a dishonorable or bad-conduct discharge is sought, the interests of the serviceman in procedural protections have been recognized

\footnotetext{
1 For the purposes of this comment, "other than honorable discharges" refers to the undesirable, bad-conduct, and dishonorable discharges, the three types which limit eligibility for veterans' benefits. See text and notes at notes 69-71 infra. The term "Iess than honorable discharges," frequently used by the courts, see, e.g., Sofranoff v. United States, $165 \mathrm{Ct}$. Cl. 470,478 (1964), adds the general discharge to the former group, reflecting the fact that any discharge except the honorable discharge has some stigmatic effect in the civilian community. See Sofranoff v. United States, supra; Army Reg. 635-212, change no. 11, at 3 (March 1, 1971); Jones, The Gravity of Administrative Discharges, 59 MrL. L. Rev. 1,25 (1973). The general discharge, however, has significantly less stigmatic effect than the other than honorable discharges. See $i d$.

2 Hearings on H.R. 523 Before Subcomm. No. 3 of the House Comm. on Armed Services, 92d Cong., 1st Sess., 6010 (table) (1971) [hereinafter cited as 1971 Hearings].

3 See, e.g., Bland v. Connally, 293 F.2d 852 (D.C. Cir. 1961); Stapp v. Resor, 314 F. Supp. 475 (S.D.N.Y. 1970); Glidden v. United States, 185 Ct. Cl. 515 (1968); Clackum v. United States, 296 F.2d 226 (Ct. CI. 1961). See also Lane, Evidence and the Administrative Discharge Board, 55 MrL. L. REv. 95, 98-100 (1972).

4 See Bland v. Connally, 293 F.2d 852, 858 (D.C. Cir. 1961); Sofranoff v. United States, 165 Ct. Cl. 470, 478 (1964); Hearings Before the Subcomm. on Constitutional Rights of the Senate Comm. on the Judiciary on the Constitutional Rights of Military Personnel, 87th Cong., 2d Sess. 187-88 (1962) [hereinafter cited as 1962 Hearings]; Jones, supra note 1, at $15,22-25$.
}

5 See text and notes at notes 61-74 infra. 
as outweighing the military's interest in a simple discharge procedure with punitive effect, and the serviceman is accorded substantial procedural protections. ${ }^{\circ}$ The major conflict between military and serviceman interests occurs when an undesirable discharge-" "an administrative separation under conditions other than honorable"

The undesirable and bad-conduct discharges are often alternative means of punishing the same offense, ${ }^{8}$ and the effects of the two penalties are substantially identical. ${ }^{\circ}$ Nevertheless, the serviceman given an undesirable discharge is denied several of the protections recognized as necessary for imposition of a bad-conduct discharge. ${ }^{10}$ This disparity has been criticized as needlessly unfair to servicemen, ${ }^{11}$ but all attempts to reform the undesirable discharge have been legislative. ${ }^{12}$ It appears, however, that the regulations governing undesirable discharges are also constitutionally deficient. The courts can remedy these deficiencies by exercising their long-recognized authority to review military administrative actions. This comment examines the due process implications of undesirable discharge procedures, using the recognized protections of the bad-conduct discharge procedure as a benchmark. ${ }^{13}$

6 For a discussion of the protections provided in courts-martial, see text and notes at notes $42-49$ infra.

7 Army Reg. 635-200, change no. 14, I 1-9f, at I-5 (Oct. 4, 1969); 32 C.F.R. \$ 41.3(n) (1972); id. $\S 730.1(\mathrm{a})(13)$ (1972) (Navy). The problem is a substantial one. The Armed Forces imposed 15,120 undesirable discharges in fiscal year 1970, the last year for which complete figures are available. Between fiscal 1967 and the first half of fiscal 1971 they imposed 36,883 undesirable discharges. 1971 Hearings, supra note 2, at 5868.

8 See text and notes at notes 15-26 infra.

9 See text and notes at notes $68-70$ infra.

10 See text and notes at notes $29-41$ infra.

11 See, e.g., Dougherty \& Lynch, Administrative Discharge: Military Justice?, 33 Geo. WASH. L. REv. 498 (1964); Everett, Military Administrative Discharge-The Pendulum Swings, 1966 Duke L.J. 41; Lynch, Administrative Discharge: Changes Needed?, 22 MAINE L. REv. 141 (1970).

12 There are two proposed administrative discharge reform bills: S. 2247, 92d Cong., 1st Sess. (1971) (the Ervin Bill), and H.R. 523, 92d Cong., 1st Sess. (1971) (the Bennett Bill). The Bennett Bill would leave the Defense Department with the authority to prescribe grounds for administrative discharge and define the rules of evidence used in board hearings. Its major change is to enact the current hearing procedures provided by 32 G.F.R. $\$ 41$ (1972) and add the power to subpoena witnesses. The Ervin Bill would enact a new chapter of Title 10 of the United States Code, dealing with administrative discharge. It would limit the grounds for undesirable discharge, provide rules of evidence for the board hearing, and require the presence of a law officer as chairman of the board. Although the Defense Department is not unsympathetic to the Bennett Bill, neither proposal has been reported out of committee for several sessions of Congress. For a detailed criticism of both bills, see Lane, supra note 3 and Lynch, supra note 11, at 158-66. A more sympathetic view of the Ervin proposals is found in Everett, supra note 11.

13 The grounds and procedures for undesirable discharge might also be attacked as denials of equal protection, particularly when undesirable discharge is imposed for acts 


\section{Grounds and Procedures for Undesirable AND BAD-CoNDUGT Discharges}

"Misbehavior that may lead to an undesirable discharge is classified under two headings: "unfitness" and "misconduct."14 Misconduct consists of prolonged AWOL, fraudulent enlistment, or civilian conviction of a crime that carries a minimum penalty of one year's imprisonment under the Uniform Code of Military Justice (UCMJ). ${ }^{15}$ Unfitness includes acts of "sexual perversion ... . drug abuse ... an established pattern for shirking . . . dishonorable failure to pay just debts, alimony, or child support ... [ [or] unsanitary habits." ${ }^{16}$ It also includes "frequent involvement of a discreditable nature with military or civilian authorities," 17 which is the most common reason for undesirable discharge. ${ }^{18}$ "Frequent and discreditable involvement" consists of repeated disciplinary encounters. These may be minor civilian or courtmartial convictions, or nonjudicial punishments given by the serviceman's commanding officer under Article 15 of the UCMJ. ${ }^{19}$ There is no further clarification of how many or what types of disciplinary actions are sufficient grounds for undesirable discharge of the "chronic military offender."20

that constitute crimes under the Uniform Code of Military Justice, 10 U.S.C. $\$ \$ 801-950$ (1970) [hereinafter cited as UCMJ]. This approach, however, has several difficulties. The fact that courts-martial can impose punishments in addition to punitive discharge makes it arguable that the recipients of undesirable discharges constitute a different class altogether. In addition, it is difficult to contend that the different levels of procedural protection have no rational relationship to legitimate military interests in discipline and efficiency. Further, no suspect classification is involved. $C f$. Frontiero v. Richardson, 411 U.S. 677 (1973). Finally, the equal protection argument proves too much. It would require the application of all the procedures of the UCMJ to the undesirable discharge, regardless of whether they are necessary to its fundamental fairness. If denial of equal protection is urged in terms of denial of fundamental rights extended to others, see, e.g., Vlandis $v$. Kline, 412 U.S. 441 (1973); Shapiro v. Thompson, 394 U.S. 618 (1969), discussion of the fundamental nature of the procedural rights is more conveniently conducted in terms of due process. The due process approach has the additional advantage of conforming to the existing terminology used in the judicial review of military judicial and administrative action. See, e.g., Burns v. Wilson, 346 U.S. 137 (1953); Clackum v. United States, 296 F.2d 226 (Ct. Cl. 1961).

1432 C.F.R. § 41.5 (c) (1972). Undesirable discharges issued for security reasons are outside the scope of this comment because of the peculiar problems surrounding the use of classified information as evidence. See id. $\S 41.6(\mathrm{~h}) ;$ id. $\$ \S 729.12(\mathrm{~g})(3)$, (7) (1972). It is also possible to request and receive an undesirable discharge "for the good of the service" in lieu of court-martial. Id. $\S 41.6(\mathrm{k})(1972)$.

15 Id. $\S 41.6(\mathrm{j})(1972)$.

$16 I d . \S \S 41.6(\mathrm{i})(2)-(7)(1972)$.

17 Id. \$ 41.6(i)(1) (1972).

181971 Hearings, supra note 2, at 5870.

19 See Army Reg. 635-212, Appendix, at 20 (July 15, 1966); 32 C.F.R. $\$ 730.12(\mathrm{~g})$ (1972). 20 See text and note at note 138 infra. 
Many of the acts justifying separation by undesirable discharge are also grounds for bad-conduct discharge after court-martial. Fraudulent enlistment ${ }^{21}$ and $\mathrm{AWOL}^{22}$ are specifically named as crimes in the Code. Drug use and dishonorable failure to pay debts are punishable under Article 134, the catch-all provision of the UCMJ. ${ }^{23}$ The Code definition of sodomy is broad enough to include acts of sexual perversion. ${ }^{24} \mathrm{An}$ established pattern for shirking may include the UCMJ crime of disobedience to lawful orders. ${ }^{25}$ Moreover, some chronic offenders may receive bad-conduct discharges for conviction of a minor offense if they have two or more previous convictions by a court. ${ }^{26}$

An undesirable discharge is given by the "discharge authority," an officer with general court-martial jurisdiction. ${ }^{27}$ No serviceman can be given an undesirable discharge without his consen $t^{28}$ unless a hearing board (the "administrative discharge board") 29 recommends it. The board consists of three officers, one of whom must be at least a major, but none of whom are required to have legal training. ${ }^{30}$ The service-

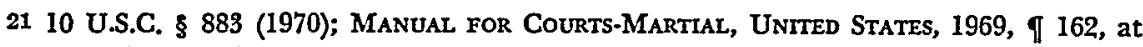
28-9 [hereinafter cited as MCM]. The maximum penalty is dishonorable discharge and one year of imprisonment. MCM I 127c, at 25-11.

2210 U.S.C. \$ 886 (1970); MCM, supra note 21, at 28-14. The maximum penalty for being AWOL more than thirty days at a time is dishonorable discharge and one year of imprisonment. AWOL for more than three but less than thirty days is punishable by six months imprisonment without discharge and two-thirds forfeiture of pay for six months. Id. I1 $127 \mathrm{c}$, at $25-11$.

2310 U.S.C. \& 934 (1970); MCM, supra note 21, I 213b, at 28-72; id. If 213f, at 2877. Possession of marijuana carries a maximum penalty of five years imprisonment and dishonorable discharge, while the penalty for hard drugs is ten years and dishonorable discharge. Id. I 127c, at 25-15. Failure to pay debts may be penalized by bad-conduct discharge and six months imprisonment. Id. But of. Levy v. Parker, 478 F.2d 772 (3d Cir. 1973); Avrech v. Secretary of the Navy, 477 F.2d 1237 (D.C. Cir.), prob. juris. noted, 94 Sup. Ct. 64 (1973).

24 "Any person ... who engages in unnatural carnal copulation with another person of the same or opposite sex or with an animal is guilty of sodomy." 10 U.S.C. § 925 (1970); MCM, supra note $21, \llbracket 204$, at 28-59. Consensual sodomy with a partner sixteen years or older carries a maximum penalty of dishonorable discharge and five years imprisonment. Id. \127c, at 25-14.

2510 U.S.C. \& 892 (1970); MCM, supra note 21, I 171, at 28-22. Knowing failure to obey a lawful order may be punished by bad-conduct discharge and six months imprisonment. Id. $\$ 127 \mathrm{c}$, at $25-12$.

28 MCM, supra note 21, I $127 \mathrm{c}$, Section B, at $25-17$. The conduct must also have been within three years of the offense for which discharge is sought. Id.

2732 C.F.R. $\S 41.7$ (d) (1972). Commanders, normally Major Generals or above, of units of division size or larger possess general court-martial jurisdiction. 10 U.S.C. $\$ 822$ (1970).

28 The most obvious reason for accepting an undesirable discharge is to avoid courtmartial. See note 31 infra.

2832 C.F.R. $\$ 41.7$ (d)(1) (1972).

30 Id. \& 41.8(a) (1972). 
man has a right to notice of the grounds for discharge, representation by counsel, and a board hearing that he may attend with counsel. ${ }^{31}$

The board develops the record on which the discharge authority acts, and can veto an undesirable discharge. ${ }^{32}$ The hearing is therefore the critical stage of the discharge process. The board is free to consider any relevant, material evidence, without regard to formal evidentiary rules. ${ }^{33}$ Although the "highest quality of evidence obtainable" is required by the Army, ${ }^{34}$ all of the services allow the use of affidavits and other written statements. ${ }^{35}$ The serviceman or his counsel may cross-examine any witness who appears and may request the production of any witness. ${ }^{36}$ The hearing board, however, can compel the attendance only of active duty personnel; it has no power to subpoena civilians. ${ }^{37}$ In lieu of an absent witness, his ex parte statements are admissible. ${ }^{38}$ The board may recommend undesirable, general, or honorable discharge ${ }^{39}$ on the basis of "reasonably satisfactory" evidence. The discharge authority may accept the recommendations or act with more lenience; he cannot order a harsher discharge than the board has found warranted..$^{40}$ Administrative review, which is not available until after discharge, presumes the correctness of the discharge. ${ }^{41}$

31 Id. § 41.8(c) (1972). These rights may be waived after consultation with counsel. Id. \$ $41.7(d)(1)$. Individuals normally waive their right to a hearing in order to accept an undesirable discharge in response to the threat of court-martial. See Haines v. United States, 453 F.2d 233 (3d Cir. 1971); 32 C.F.R. § 41.6(k) (1972); 1962 Hearings, supra note 4, at 139. The Air Force has found that the majority of airmen processed for undesirable discharge waive their hearing rights "for reasons best known to themselves." 1962 Hearings, supra note 4 , at 141 .

3232 C.F.R. § 41.4(a)(2) (1972).

33 Id. § 41.8(b); Army Reg. 15-6, ๆ 10, at 5 (Aug. 12, 1966); 32 C.F.R. § 730.15(d)(1) (1972) (Navy); cf. id. \& 866.9(b) (1972) (Air Force).

34 Army Reg. 15-6, ๆ 9(1) (Aug. 12, 1966); cf. 32 C.F.R. $\$ 866.9$ (a) (1972) (Air Force).

35 Army Reg. 15-6, ๆ $9(1)$ (e), (g) (Aug. 12, 1966); AIR Force MANual 39-12 (summarized in 1971 Hearings, supra note 2, at 5884); 32 C.F.R. \& 730.15(d) (1972) (Navy); see Lynch, supra note 11, at 153-54; cf. 32 C.F.R. § 41.8(b) (1972).

36 Army Reg. 635-212, Iף 17c(2)(c), (f), at 10-12 (July 15, 1966); 32 C.F.R. §§ 730.15(e)(4), (7) (1972) (Navy).

3732 C.F.R. $\$ \$ 41.8(c)(3), 730.15(b)$ (1972). Furthermore, volunteer civilian witnesses must appear at no expense to the government. $I d$.

38 See Dougherty \& Lynch, supra note 11, at 512; Lynch, supra note 11, at 154.

3932 C.F.R. \& 41.8(b) (1972); Army Reg. 635-212, I 17d, at 12 (July 15, 1966). The standard of proof in administrative discharge hearings is apparently substantial evidence. See Army Reg. 15-6, I 20, at 7 (Aug. 12, 1966). The Navy does not specify a standard of proof, but the Marine Corps requires a "preponderance of the evidence." 32 C.F.R. $\S 730.73(\mathrm{c})(20)(1972)$.

4032 C.F.R. \$ 41.8(d) (1972); Army Reg. 635-212, ๆ 19d (July 15, 1966).

41 See Joint Hearings Before the Subcomm. on Constitutional Rights of the Senate Comm. on the Judiciary and a Special Subcomm. of the Senate Comm. on Armed Services, 
The bad-conduct discharge, on the other hand, can be imposed only by a special or general court-martial, ${ }^{42}$ at which a military judge presides. ${ }^{43}$ That tribunal has the same subpoena powers as a United States District Court,44 and, "so far as not otherwise prescribed," follows the "rules of evidence generally recognized in the trial of criminal cases in the United States district courts." 45 The defendant may crossexamine all witnesses, ${ }^{46}$ and is provided with counsel certified competent to practice in the most serious military trials. ${ }^{47}$ The discharge can be imposed only if the defendant is found guilty beyond a reasonable doubt of the offense charged or a lesser included offense for which punitive discharge is authorized. ${ }^{48}$ The discharge takes effect only after administrative and judicial review. .9

The procedures for imposing a bad-conduct discharge give the potential recipient a high level of protection. When an undesirable discharge is imposed, however, important procedural protections are lacking. Three of these deficiencies-the denial of subpoena powers and the right of confrontation, the low standard of proof, and vagueness of the definition of acts justifying "chronic offender" discharge-deprive the discharge recipient of due process of law.

\section{Due Process Considerations}

Due process of law in an administrative proceeding is not an absolute standard. Denomination of the individual interest as a "right" or "privilege" is no longer significant. ${ }^{50}$ Described by Justice Frankfurter

89th Cong., 2d Sess. 390-91 (1966) [hereinafter cited as 1966 Hearings]; Dougherty \& Lynch, supra note 11, at 519-22. The progress of a typical undesirable discharge case through the administrative process is described, id. at 501-16, and illustrated for the guidance of discharge board members in Army Reg. 635-212, Appendix (July 15, 1966).

4210 U.S.C. §§ 818-19 (1970); MCM, supra note 21, \$\$ 14-15, at 4-1-6. A summary court-martial cannot impose punitive discharge. 10 U.S.C. \& 820; MCM, supra note 21, If 16 , at $4-6$.

4310 U.S.C. $\$ 8826(\mathrm{a}), 819$ (1970); MCM, supra note 21, ๆ 15b, at 4-5. Military judges are lawyer-officers, certified competent in military law, who are normally assigned to judicial duties. 10 U.S.C. $\$ 826$ (b) (1970); MCM, supra note 21, ๆ 4e, at 2-3.

4410 U.S.C. \& 846 (1970); MCM, supra note 21, ๆ 115d, at 23-2.

45 MCM, supra note $21, \mathbb{1 3 7}$, at $27-4$.

46 Id. If $149 \mathrm{~b}$, at $27-54$.

47 10 U.S.C. $\$ \$ 819,827$ (b) (1970); MCM, supra note 21 , ๆ 14b, at 4-4.

4810 U.S.C. \& 851(c) (1970); MCM, supra note 21, I 74a(3), at 13-4; id. If 76a(4), at $13-13 ; i d$. ๆ $127 \mathrm{c}$, at $25-17$.

49 A court-martial sentence including a bad-conduct discharge must be approved by a commander having general court-martial jurisdiction and then by the Court of Military Review before the discharge takes effect. 10 U.S.C. §§ 865(b), 866(b) (1970); MCM, supra note 21, I 84d, at 17-2; id. I 98, at 20-1.

б0 Graham v. Richardson, 403 U.S. 365, 374 (1971); Bell v. Burson, 402 U.S. 535, 539 (1971). The individual interest still must fit, however, under the "liberty" or "property" 
as "fundamental fairness," 51 due process in administrative proceedings varies with the nature of the governmental function and the seriousness of the potential harm to the individual. ${ }^{52}$ An individual's opportunity to challenge facts on which the government will act must be proportionate to the injury that may be inflicted by erroneous action, discounted by the government's need for speed, economy, secrecy, or maintenance of an efficient governmental organization..$^{53}$

Administrative discharges from the Armed Forces are reviewable in the federal courts on three grounds: ${ }^{54}$ failure to follow regulations, ${ }^{55}$ lack of statutory authority to discharge,,$^{56}$ and failure to provide due process. ${ }^{57}$ In Clackum v. United States, ${ }^{58}$ the Court of Claims held that

rubrics of the fourteenth amendment. Fuentes v. Shevin, 407 U.S. 62, 83 (1972). "Property" appears to require at least a reasonable expectation of a public benefit. Compare Board of Regents v. Roth, 408 U.S. 564, 577 (1972) with Perry v. Sindermann 408, U.S. 593, 60102 (1972). "Liberty" includes both public reputation, Wisconsin v. Constantineau, 400 U.S. 433 (1970), and the ability to obtain employment, Greene v. McElroy, 360 U.S. 474, 492 (1959). But see Board of Regents v. Roth, supra, at 573-75; Cafeteria Workers Local 473 v. McElroy, 367 U.S. $886,895-96$ (1961). The dishonorable discharge clearly fits these definitions. See text and notes at notes 61-74 infra.

51 Joint Anti-Fascist Refugee Comm. v. McGrath, 341 U.S. 123, 161 (1951) (concurring opinion).

52 Morrissey v. Brewer, 408 U.S. 471, 481 (1972); Goldberg v. Kelly, 397 U.S. 254, 263 (1970); Joint Anti-Fascist Refugee Comm. v. McGrath, 341 U.S. 123, 162-63 (1951) (Frankfurter, J. concurring); cf. In re Gault, 387 U.S. 1 (1967).

531 k.C. Davis, Administrative Law Treatise § 7.02, at 412 (1958); see, e.g., Morrissey v. Brewer, 408 U.S. 471 (1972); Goldberg v. Kelly, 397 U.S. 254 (1970); cf. Perry v. Sindermann, 408 U.S. 593 (1972).

54 Birt v. United States, $180 \mathrm{Ct}$. Cl. 910, 913 (1967). Judicial review of an undesirable discharge is limited to the "legal sufficiency" of the discharge. $I d$. It is available through two procedures. A discharged serviceman may request a declaratory judgment that the discharge is void and a mandatory injunction for the issuance of an honorable discharge, e.g., Stapp v. Resor, 314 F. Supp. 475 (S.D.N.Y. 1970), or he may sue in the Court of Claims for the back pay he would have received had he completed his enlistment, e.g., Clackum v. United States, 296 F.2d 226 (Ct. Cl. 1960). In the latter instance, judgment for the serviceman does not itself upgrade the discharge, but it does require a finding that the discharge was wrongfully issued. This collaterally estops the government from asserting the existence of an other than honorable discharge in any future proceeding. See Meador, Judicial Determinations of Military Status, 72 YALE L.J. 1293, 1304-06 (1963). See generally Suter, Judicial Review of Military Administrative Decisions, 6 Houston L. REv. 55 (1968). Most successful attacks on undesirable discharges rely on the failure of the service to follow its own procedural regulations. Everett, supra note 11, at 75-78. Constitutional issues raised by such attacks have been avoided by finding lack of statutory authority to discharge, e.g., Harmon v. Brucker, 355 U.S. 579 (1958); by finding violations of procedural regulations, e.g., Glidden v. United States, $185 \mathrm{Ct}$. Cl. 515 (1968); or by holding the challenge to be procedurally premature, e.g., Crawford v. Davis, $249 \mathrm{~F}$. Supp. 943 (E.D. Pa. 1966). For cases dealing with the problems caused by premature attempts at judicial review of a discharge, see note 120 infra; Suter, supra, at 78-77.

55 E.g., Conn v. United States, 376 F.2d 878 (Ct. Cl. 1967).

56 E.g., Harmon v. Brucker, 355 U.S. 579 (1958).

67 Clackum v. United States, 296 F.2d 226 (Ct. Cl. 1960). 
regulations permitting an undesirable discharge without notice and a hearing denied due process. It reasoned that:

[T] he Air Force had the undoubted right to discharge [Clackum] whenever it pleased, for any reason or for no reason, and by so doing preserve the Air Force from even the slightest suspicion of harboring undesirable characters. But it is unthinkable that it should have the raw power, without respect for even the most elementary notions of due process of law, to load her down with penalties. It is late in the day to argue that everything that the executives of the armed forces do in connection with the discharge of soldiers is beyond the reach of judicial scrutiny. ${ }^{59}$

Clackum stands for two important principles. First, the undesirable discharge is a penalty, and the serviceman has a right to procedural safeguards in any proceeding through which such penalties may be imposed. Second, the military remains free to discharge anyone under conditions characterized as honorable or as undesirable, but any limits on the procedural safeguards of a discharge with punitive effects must be justified by a military interest that outweighs the recipient's interest in not being subject to erroneously inflicted injury. The courts must therefore carefully examine the individual and military interests to be balanced in determining the requirements of due process.

\section{A. The Injury to the Individual}

Any discharge from the military injures the unwilling recipient by depriving him of his chosen career and foreclosing retirement benefits. ${ }^{60}$ Undesirable and bad-conduct discharges additionally cause denial of veterans' benefits and injury to the recipient's reputation, both of which reduce his employment and educational opportunities. In the undesirable discharge situation, the serviceman's interest in protections that will prevent erroneous imposition of these penalties is increased by the particularly error-prone nature of the proceeding.

1. Civilian Consequences of an Undesirable Discharge. The undesirable discharge officially labels an individual as unfit to serve in the Armed Forces because of criminality, sexual deviancy, drug use, or simply resistance to authority. ${ }^{61}$ His military record is thrown into

68 Id.

60 Id. at 228.

60 The military interest in eliminating unproductive personnel has been recognized as sufficiently strong to justify discharge without a hearing where the discharge is "under honorable conditions" and provides full veterans' benefits. Birt v. United States, $180 \mathrm{Ct}$. Cl. 910 (1967); cf. Reed v. Franke, 187 F. Supp. 905 (E.D. Va. 1961), affd, 297 F.2d 17 (1961); Rowe v. United States, 167 Ct. Cl. 468 (1964).

61 see text and notes at notes 14-26, supra. The stigmatization is particularly strong 
high relief by the overwhelming majority of veterans with honorable discharges. ${ }^{62}$ A recent study found that two-thirds of a nationwide sample of employers asked job applicants how they had been discharged from the military. More than one-fourth of those who inquired automatically rejected anyone with an undesirable discharge, and a large majority of the other three-fourths were influenced in their hiring decisions by the type of discharge. ${ }^{63}$ These findings confirm the impressions of the witnesses before the Ervin Subcommittee on Constitutional Rights. ${ }^{64}$ The harm to employment potential is greatest in jobs requiring either reputable character or a security clearance. ${ }^{65}$ Licensed professional employment is sharply curtailed. ${ }^{68}$ Although an undesirable discharge does not automatically bar civilian employment with the United States, it interferes with security clearance and denies the potential employee his Civil Service veterans' preference. ${ }^{67}$

Numerous decisions have recognized that undesirable and bad-conduct discharges have essentially identical effects on recipients. ${ }^{68}$ The Court of Claims has stated: "To the public generally, a less-than-honorable discharge carries the damaging implication that an individual has been declared unfit for retention in the Armed Forces of the United States. Often, the difference between an undesirable and a dishonorable discharge is one which is either misunderstood or has no connotation

with respect to homosexuality; because many homosexuals receive an undesirable discharge, all recipients of the discharge may be suspected of homosexuality. See 1966 Hearings, supra note 41 , at 335 .

62 During 1962-1965 honorable discharges constituted approximately 93 percent of the enlisted separations from the Army. Id. at 1036. Although the proportion of less than honorable discharges increased during the later stages of the Vietnam War, honorable discharges continued to account for over 90 percent of enlisted separations. 1971 Hearings, supra note 2, at 5868-70. Judicial recognition of the normality of the honorable discharge appears in Bland v. Connally, 293 F.2d 852, 858 n.1 (D.C. Cir. 1961) and Sofranoff v. United States, $165 \mathrm{Ct}$. Cl. 470, 478 (1964).

63 Jones, supra note 1 , at 18-20; cf. Dougherty \& Lynch, supra note 11, at 517 n.85. Although commentators agree that the undesirable discharge has some prejudicial effect on employment, id. at 499-500; Everett, supra note 11, at 45 \& n.21; Lane, supra note 3, at 97-100, only Captain Jones has attempted a statistical verification.

64 See, e.g., 1962 Hearings, supra note 3, at 187-88 (Chief Judge Quinn, Court of Military Appeals), 328 (Congressman Doyle), 336 (Mr. Charles Mayer). Military witnesses conceded the existence of the stigma but considered it appropriate. E.g., id. at 10 (Assistant Secretary of Defense Runge); see Lane, supra note 3, at 99-100; text and notes at notes 86-92 infra.

65 See 1962 Hearings, supra note 4, at 188; Jones, supra note 1, at 13-14.

68 Jones, supra note 1 , at 20.

67 See id. at 12-13.

68 E.g., Van Bourg v. Nitze, 388 F.2d 557 (D.C. Cir. 1967); Stapp v. Resor, 314 F. Supp. 475 (S.D.N.Y. 1970); Glidden v. United States, 185 Ct. Cl. 515 (1968). Other cases are collected in Jones, supra note 1 , at 15 n.72. 
whatever."'69 Although employers show some recognition of the difference between undesirable and bad-conduct discharges, the departure from the norm of honorable discharge is much more important to them than finely distinguished shades of disapprobation..$^{70}$

The federal government itself takes even less cognizance of these technical distinctions than do employers. Undesirable and bad-conduct discharges identically affect eligibility for statutory benefits not administered by the Veterans Administration, such as reemployment rights and Civil Service preferences. ${ }^{71}$ Eligibility for Veterans Administration benefits, such as hospitalization and medical care, educational payments, and guaranteed loans, requires a discharge "under conditions other than dishonorable," 72 which may include either an undesirable discharge or a bad-conduct discharge issued by a special court martial. ${ }^{73}$ Either discharge, if issued for willful and persistent misconduct, homosexual acts, or conviction of a crime involving moral turpitude, deprives the recipient of benefits. ${ }^{74}$

2. Institutional Bias. The magnitude of an individual's interest in procedural protections is affected not only by the severity of the consequences he faces but also by the structure of the adjudicating agency. ${ }^{75}$ The institutional characteristics of the undesirable discharge proceeding create a strong possibility of undue severity.

69 Conn v. United States, 376 F.2d 878, 881 (Ct. Cl. 1967)..

70 Jones concludes that 75 percent of those he surveyed are negatively influenced by the bad-conduct discharge, 69 percent by the undesirable discharge, and 51 percent by the general discharge (supposedly under "honorable conditions"). Broken down by employer type, his data shows that of those in big business, for example, 77 percent were negatively influenced by an undesirable discharge and 81 percent were so influenced by a bad-conduct discharge. Among bar examiners, the figures were 82 percent for the undesirable discharge and 85 percent for the bad-conduct. For methodology and complete data, see Jones, supra note 1, at 16-18 and 22-24.

71 Department of the Army Graphic Training Aid 21-2-1, reprinted in 1971 Hearings, supra note 2, at 6010. Doubtful cases from other agencies are often referred to the Veterans Administration for decision. Id. at 6008,6012 .

7238 U.S.C. § 101(2) (1970); 38 G.F.R. \$ 3.12(d) (1973); see 1971 Hearings, supra note 2, at 6007-10.

73 The term is defined by the Veterans Administration through a determination on a case by case basis of whether the grounds for the discharge involved "moral turpitude" or "persistent" misconduct. 1971 Hearings, supra note 2, at 6009-10.

74 Id. A bad-conduct discharge issued by a general court-martial, however, bars Veterans Administration benefits absolutely. 38 U.S.C. $\$ 3103(\mathrm{a})$; 38 C.F.R. $\$ 3.12$ (c)(2) (1972).

75 See Morrissey v. Brewer, 408 U.S. 471, 485-86 (1972); Goldberg v. Kelly, 397 U.S. 254, 269 (1970); cf. Fuentes v. Shevin, 407 U.S. 67, 80-81 (1972). Bias in the sense of policy preference in discretionary decisions must be distinguished from bias which prevents objective consideration of the factual grounds for taking any action at all. Cf. Morrissey v. Brewer, supra, at 479-80. The former, though perhaps reprehensible, is not considered a denial of due process. See FTC v. Cement Institute, 333 U.S. 683, at 702-03 (1948); 2 K.C. DAvis, supra note 53, $\S 12.01$, at 145 (1958). It is difficult, however, to distinguish 
- Unlike the involuntary disabilities that lead to honorable or general discharge, the grounds for undesirable discharge are voluntary acts, ${ }^{76}$ and therefore are likely to provoke personal hostility from the officers accusing the serviceman. His formal accuser is always his commanding officer, ${ }^{77}$ who may regard the proceeding as a personal contest of will with a rebellious subordinate. If the serviceman is accused of "frequent and discreditable involvement," the principal witnesses against him are his immediate military superiors; 78 if he is accused of homosexuality, they are military chaplains and doctors. ${ }^{79}$ The administrative discharge board is likely to give their allegations great weight.

The hearing board is composed of temporarily assigned officers who are normally in command of troops. Many have commanded "undesirable" servicemen; the rest may reasonably expect to do so. They are likely to identify strongly with the commander, who needs to maintain discipline by removing troublesome personnel. They are also likely to overestimate the problems a commander may face if other soldiers doubt the swiftness and certainty of undesirable discharge-regardless of the recipient's culpability. ${ }^{80}$

The weight of military testimony and the inherent bias of the discharge board permit abuse by commanders. The previous disciplinary record that justifies discharge for "frequent and discreditable involvement" can be built by a hostile company commander through imposition of nonjudicial punishments. ${ }^{81}$ In particular, the strong desire to remove the suspected homosexual as quickly as possible ${ }^{82}$ may lead to exaggeration of the case against him. A certain amount of institutional bias is also present in the special court-martial situation, ${ }^{83}$ but the

between a constitutionally acceptable policy preference for removing from the military certain classes-for example, homosexuals or chronic offenders-and a prejudice which denies due process by discounting the factual contentions of individuals accused of belonging to that class. See id. $\S 12.02$, at 146-48; K.C. Davis, Administrative Law Treatise $\S 12.02$, at 437 (Supp. 1970).

76 Compare 32 C.F.R. $\S \S 41.6(\mathrm{~h})-(\mathrm{j})$ with id. $\S 41.6(\mathrm{~g})$ (1972). The common factor in the grounds for discharge for unsuitability is that there are "significant observable defects apparently beyond the control of the individual." Id. § $41.6(\mathrm{~g})(3)(1972)$.

77 See, e.g., Army Reg. 635-212, ๆ 12 (July 15, 1966).

78 See id., Appendix (July 15, 1966).

78 See, e.g., Weir v. United States, 474 F.2d 617 (Ct. Cl. 1973).

80 No attempt will be made to explore the problem of the permissible extent of command influence on military fact finding bodies, a problem inherent in both administrative discharge and court-martial procedures. See, e.g., Cole v. United States, $171 \mathrm{Ct}$. Cl. 178 (1965). See generally Everett, supra note 11, at 80-81; West, A History of Command Infiuence on the Military Judicial System, 18 U.C.L.A.L. REv. 1 (1970).

81 See note 101 infra.

82 See note 85 infra; cf. Benson v. Holloway, 312 F. Supp. 49 (D. Neb. 1970).

83 The UCMJ does attempt to limit command influence on courts-martial by prohibiting 
greater potential for abuse of the undesirable discharge can hardly be read as justifying fewer procedural protections.

\section{B. The Military Interest}

The undesirable discharge is not needed as a fast and simple procedure for removing unwanted personnel from the service. Summarily imposed general or honorable discharges effectively serve that need. Where punitive action is the only need, the bad-conduct or dishonorable discharge can be imposed through court-martial. The only interest that is served by the undesirable discharge, therefore, is the need for a discharge procedure that results in punitive consequences without the formality and expense of court-martial. ${ }^{84}$ An undesirable discharge is attractive to the Armed Forces when court-martial would be redundant (where the serviceman has been convicted by a civilian court); unavailable (where he is a chronic military offender) ; or unlikely to lead to conviction (where he could be prosecuted under the UGMJ, but the case against him is weak). ${ }^{85}$

An undesirable discharge that reflects a civilian conviction serves a special service interest because the Supreme Court has eliminated courts-martial jurisdiction over non-service-connected crimes. ${ }^{86}$ It is not possible to give these men bad-conduct or dishonorable discharges, ${ }^{87}$ yet some form of separation noting that their service ended because of a felony conviction is appropriate. Procedural safeguards are provided when guilt is determined in the civilian court; it would be pointless to

evaluation or censure of court members or counsel based on their performance. 10 U.S.C. $\$ 837$ (1970); MCM, supra note 21, I 38, at 8-3-4. See generally West, supra note 80.

84 Bland v. Connally, 293 F.2d 852, 858 (D.C. Cir. 1961).

85 See 1966 Hearings, supra note 41, at 361-80 (Brigadier General Berg, Deputy Assistant Secretary of Defense); 1962 Hearings, supra note 4, at 139. The desire to evade the strictures of the UCMJ is particularly pronounced where homosexuality is alleged. See 1966 Hearings, supra note 41 , at $87-88,131,382,393 ; 1962$ Hearings, supra note 4 , at 10, 20$22,50$.

86 O'Callahan v. Parker, 395 U.S. 258 (1969). The concept of "service connection" is not, however, free from ambiguity. See Relford v. Commandant, United States Disciplinary Barracks, 401 U.S. 355 (1971). The restriction on jurisdiction extends only to crimes committed within the jurisdiction of American civilian courts. United States v. Keeton, 19 U.S.C.M.A. 64, 41 C.M.R. 64 (1969). Nevertheless, it is the policy of the Armed Forces not to prosecute an individual who has been tried in a foreign court. Agreement Between the Parties to the North Atlantic Treaty Regarding the Status of their Forces, June 19, 1951, art. VII, para. 8, 4 U.S.T. 1792, 1802; 1966 Hearings, supra note 41, at 364-65. See also Wilson v. Girard, 354 U.S. 524 (1957) (manslaughter of Japanese civilian, soldier released to Japanese courts); 32 C.F.R. § 151.3 (1972).

87 The dishonorable and bad-conduct discharges can be given only by court-martial. See Army Reg. 635-200, change no. 5, Tी 1-5, I1-1 (June 12, 1968); Pasley, Sentence First -Verdict Afterwards: Dishonorable Discharges Without Trial By Court Martial, 41 CORNELL L. Rev. 545, 551-55 (1956). 
repeat them when acting on the record of that conviction. The military interest in an informal, inexpensive procedure thus appears quite strong in these circumstances.

The undesirable discharge is primarily used, however, to discipline the chronic military offender, who is suspected of seeking an easy way out of the service. ${ }^{88} \mathrm{He}$ has "frequent and discreditable involvements," but no crimes serious enough for discharge by court-martial. ${ }^{89} \mathrm{He}$ is described by military spokesmen as "the person who does not break the line; he does not necessarily go a.w.o.1., . . . steal[,] or refuse to obey. It is just a repetition, a constant disciplinary problem, not reaching the point of trial, but ... of no value to the command ...."90 These individuals are a burden on the service, and if they cannot be rehabilitated they must be separated. ${ }^{91}$ Yet deliberate resistance would be a rational strategy for the unwilling soldier if honorable separation were the only available procedure short of a punitive discharge by courtmartial. He could force an early separation and escape the burdens of his full enlistment without disadvantage. The threat of a "chronic offender" undesirable discharge is meant to raise the cost of escaping the obligations of military service. ${ }^{92}$ This is clearly a valid military in-

88 In the Air Force, for example, frequent and discreditable involvement is the ground for between 25 and 30 percent of undesirable discharges. The next most common grounds are drug abuse and sexual perversion. 1971 Hearings, supra note 2, at 5887.

89 The chronic military offender with two minor court-martial convictions could be given a bad-conduct discharge upon his third conviction. See note 26 supra. This would require his commander to build a record for eventual discharge by dealing with minor misconduct through court-martial instead of nonjudicial punishment. The policy of the Armed Forces, however, is to use nonjudicial punishment for minor offenses because it is swifter, more lenient, and carries fewer long-term consequences than court-martial. 1966 Hearings, supra note 41, at 372-74. Exclusive reliance on the "two-conviction" rule would compel the company commander to treat each incident as part of a potential foundation for a punitive discharge, instead of as an isolated transgression to be corrected and hopefully forgotten.

801962 Hearings, supra note 4, at 22; cf. id. at 50,63.

91 See 1966 Hearings, supra note 41, at 360; 1962 Hearings, supra note 4, at 10, 50.

92 See 1962 Hearings, supra note 4, at 50. See generally R. POSNER, ECONOMIC ANALYsis OF LAW $\$ 25.6$, at 368 (1972). A bizarre example of the lengths taken to get out of the Army is Weir v. United States, 474 F.2d 617 (Ct. Cl. 1973). Weir received a general discharge for homosexual tendencies after successfully lying about them to a chaplain, his commanding officer, and an Army psychiatrist. He sued for back pay in the Court of Claims, arguing that the Army had not followed its own regulations. Had his superiors investigated his self-accusations of homosexuality, as required by Army regulations, they would perhaps have caught him in his lie. Since they did not catch him, Weir maintained, the regulation had not been complied with. The Court of Claims was not persuaded.

Using the undesirable discharge to "prevent the dilution of the honorable discharge," 1962 Hearings, supra note 4, at 131, is merely another expression of deterrence. The honorable discharge is recognized as the overwhelming norm, but it is not given as a matter of course. "Proper military behavior and proficient performance of duty" are required for an honorable discharge. 32 G.F.R. § 41.5(a) (1972). Military spokesmen con- 
terest; less clear is the extent to which this interest justifies denials of procedural protections.

Different military interests are involved when the serviceman is processed for an act that could be dealt with by court-martial and punitive discharge. In those cases, an undesirable discharge is concededly used to avoid court-martial protections when the complainant is unable to testify, or when a requirement of proof beyond a reasonable doubt standard would thwart conviction..$^{93}$ Where homosexuality is alleged, the use of a lower standard of proof has been defended on the ground that unit morale would suffer if the troops were forced to associate with a man under even a "strong suspicion" of homosexuality ${ }^{94}$ An undesirable discharge for acts constituting crimes under the UCMJ has also been used where search and seizure protections would interefere with the evidence admissible in a court-martial. ${ }^{95}$ The "UCMJ" undesirable discharge serves the same purposes as a courtmartial: determination of guilt or innocence and punishment for crime. ${ }^{96}$ Because a functioning military judicial system is available, there is little legitimate need for administrative processing of these offenders. Inflicting punishment without the procedural constraints that the Constitution and Congress impose is not a valid military interest. ${ }^{97}$

\section{Specifig Applications of Due Process}

The Armed Forces' regulations deny the potential recipient of an undesirable discharge three important procedural protections that are recognized as necessary for a bad-conduct discharge: the right to subpoena and to cross-examine witnesses; the requirement of proof beyond a reasonable doubt; and the right to an adequate definition of the acts constituting violations.

The lack of these protections does not greatly prejudice the service-

sider it unfair not to distinguish those who accepted the burden of military service from those who deliberately shrugged it. 1962 Hearings, supra note 4, at 50. Not only is it unfair, it is also considered harmful to discipline to "negate the incentives now operating in favor of truly honorable service." $I d$.

93 See 1966 Hearings, supra note 41, at 87-88, 368; 1962 Hearings, supra note 4, at 2022, 139.

94 1962 Hearings, supra note 4, at 21-22.

95 E.g., Crawford v. Davis, 249 F. Supp. 943, 948-49 (E.D. Pa. 1966); cf. Pickell v. Reed, 326 F. Supp. 1086 (N.D. Cal. 1971) where illegal search issues existed but were not raised. See generally Lane, supra note 3, at 108-10.

86 See text at notes 15-26 supra; cf. In re Gault, 387 U.S. 1, 27-30 (1967).

97 Clackum v. United States, 296 F.2d 226, 228 (Ct. Cl. 196I); cf. Kauffman v. Secretary of the Air Force, 415 F.2d 991, 997 (D.C. Cir. 1969). 
man convicted in a civilian court. ${ }^{98}$ In prosecutions for frequent and discreditable involvement, however, these deficiencies present more difficult problems. In those cases, the discharge decision focuses on a record of previous minor court-martials and nonjudicial punishments, ${ }^{99}$ which is only a summary of the charges and the actions taken. ${ }^{100}$ The nonjudicial punishments have been imposed by the serviceman's commanding officer without effective procedural safeguards. ${ }^{101}$ The hearing board must determine whether this record of previous punishments, as amplified and explained by other evidence, warrants an undesirable discharge, a more creditable discharge, or rehabilitation. Its decision, though discretionary, depends on findings of fact which the serviceman has a strong interest in contesting.

The serviceman's interest in fully presenting his case is even more compelling when he is accused of a crime punishable under the UCMJ. In those cases the discharge board makes the only determination of guilt and imposes punishment, and the safeguards in that hearing are the only ones the serviceman will receive. The only military interests served by this proceeding are administrative convenience and avoidance of the protections of the court-martial. In sharp contrast, the serviceman's civilian future may be blighted by the unjustified imposition of a penalty having the effect of a conviction. ${ }^{102}$

In the "civilian conviction" case, the military interest seems to justify the truncated proceeding, and in the "UCMJ" situation the military does not appear to have any interests sufficient to justify denying procedural protections. The military interests are greater in the "chronic offender" situation than in the "UCMJ" discharge, but the balancing of interests in both "UCMJ" and "chronic offender" proceedings deserves closer examination in the context of the particular protections denied.

98 See note 108 infra.

99 See, e.g., Army Reg. 635-212, Appendix (July 15, 1966) which is a sample of the complete record of an undesirable discharge proceeding based on frequent and discreditable involvement. See 1966 Hearings, supra note 41, at 372-73.

100 The summary records of previous convictions and nonjudicial punishments are shown in Army Reg. 635-212, Appendix, at 32-38 (July 15, 1966). The record of nonjudicial punishment need not contain any elaboration of the facts beyond a bare specification of the charge. E.g., id. at 33. See also MCM, supra note 21, I 133a. The record of a summary court-martial contains no abstract of the evidence. Id., Appendix 11.

101 The serviceman given nonjudicial punishment under Article 15 of the UCMJ, 10 U.S.C. $\S 815$ (1970), is punished by his company or battalion commander, who is also the prosecutor. The serviceman has no right to counsel, confrontation, or cross-examination. The soldier may refuse Article 15 punishment, but by doing so he risks greater punishment. See generally Note, The Unconstitutional Burden of Article 15, 82 Yale L.J. 1481, 1484 n.12 (1973).

102 See text and notes at notes $61-74$ supra. 


\section{A. Confrontation and Subpoena}

The Supreme Court has explicitly recognized the importance of both the right of confrontation ${ }^{103}$ and the right of a defendant to subpoena witnesses in his behalf. ${ }^{104}$

In the special court-martial context it has been established that the rights of confrontation and cross-examination are constitutionally required. ${ }^{105}$ It has also been explicitly stated that the right to subpoena witnesses, as guaranteed by the Sixth Amendment, applies to courtmartial proceedings. ${ }^{108}$ In the undesirable discharge situation, however, both rights are severely circumscribed.107

Cross-examination is of special significance where the justification for an undesirable discharge is "frequent and discreditable involvement." 108 The record of previous punishments usually requires amplification by witnesses-often current and former superiors, who are normally available without subpoena ${ }^{109}$ - to both the recorded incidents and the present usefulness of the serviceman. In cases of drug use, sex offenses, or failure to pay debts, civilian testimony can be critical. ${ }^{110}$

Undesirable discharge hearings based on crimes under the UGMJ present essentially the same evidentiary problems as prosecution before a special court-martial; only the gravity of the maximum penalties

103 See, e.g., Greene v. McElroy, 360 U.S. 474 (1959).

104 See, e.g., Washington v. Texas, 388 U.S. 14 (1967).

105 United States v. Jacoby, 11 U.S.C.M.A. 428, 29 C.M.R. 244 (1960).

106 United States v. Sweeney, 14 U.S.C.M.A. 599, 34 C.M.R. 379 (1964); cf. United States . v. Thornton, 8 U.S.C.M.A. 446, 24 C.M.R. 256 (1957).

107 The board's lack of subpoena power and its informal rules of evidence allow the prosecution to introduce statements from unavailable witnesses. The lack of subpoena power also limits the serviceman's ability to produce civilian witnesses in his own behalf. See text and notes at notes 33-38 supra.

108 See text and notes at notes 99-101 supra. Because the evidence in discharge proceedings for civilian conviction consists almost exclusively of judicial records, crossexamination is not important. A board of three legally untrained individuals, furthermore, is not the appropriate form for collateral attack on a civilian criminal conviction.

108 See Army Reg. 635-212, Appendix, at 24-30 (July 15, 1966). Although the Army provides for the transfer of chronic military offenders to give them a second chance in another unit, the transfer is normally confined to the same post or area. Army Reg. 635212, change no. 11, $\{\Upsilon 7 \mathrm{~b}(2),(3)$ (March, 1971). Unavailability of witnesses who might be transferred is covered by Army Reg. 635-212, I 14d (July 15, 1966); the discharge authority is directed to retain such persons in his command unless their legal term of enlistment has expired and they must be discharged. Discharged witnesses are beyond military control and cannot be ordered to appear, although the commander is directed to obtain their depositions or affidavits before discharge. $C f$. text and notes at notes 35-38 supra.

110 E.g., Glidden v. United States, 185 Ct. Cl. 515 (1968); 1962 Hearings, supra note 4, at 139; see Lynch, supra note 11 , at 154-55; Note, Imprisonment for Debt: In the Military Tradition, 80 YALE L.J. 1679, 1682-85, 1685-88 (1971). 
differs. The six-month imprisonment which a special court-martial can impose is insignificant beside the continuing civilian consequences of undesirable discharge. Confrontation and subpoena rights in the undesirable discharge situation should therefore accord with the rights of the serviceman in courts-martial. In courts-martial the rules for compelling attendance by civilian witnesses are virtually the same as in criminal proceedings in the federal courts. ${ }^{111}$

The discharge board that conducts an undesirable discharge proceeding, in stark contrast, has no power to compel the attendance of civilian witnesses, irrespective of the materiality of their testimony or convenience of attendance. ${ }^{112}$ There are no cases that hold cross-examination or subpoena powers to be an element of fundamental fairness in this situation, but three cases suggest it. In Bland $v$. Connally, ${ }^{113}$ the Court of Appeals for the District of Columbia Circuit avoided the confrontation issue, basing its decision on statutory grounds. The court stated, however, that if forced to decide whether cross-examination in an administrative discharge proceeding is required by due process, it would "seriously doubt whether the Constitution would condone the infliction of such injury, in the service of an interest so

111 See note 45 supra. The military judge, however, is permitted to balance convenience of attendance against materiality of testimony in deciding whether to issue a subpoena to a civilian. MCM, supra note 21, If 115a, at 23-1. The power to compel the attendance of military witnesses on active duty is the same for discharge boards and courts-martial. The Army provides for the attendance of military witnesses unless they "reside or are on duty at a substantial distance from the installation at which the hearing is being conducted." Army Reg. 15-6, I 13b (Aug. 12, 1966); cf. MCM, supra note 21, II 115a, b, at 23-I-2. If this inconvenience arises in a court-martial, only deposition evidence may be substituted. See MCM, supra note 21, If 145a, at 27-42; id. If 146b, at 27-47; cf. 10 U.S.C. § 849(d) (1970). In undesirable discharge proceedings, however, mere statement evidence may also be substituted. E.g., Army Reg. 15-6, I 9 (Aug. 12, 1966). The accused has the right to be present in person and to have counsel for cross-examination when a deposition is taken for use as evidence in a court-martial. United States v. Giles, 42 G.M.R. 880 (Ct. of Mil. Review 1970); MCM, supra note 21, I $117 \mathrm{~b}(2)$, at 23-5. Deposition evidence is admissible in courts-martial only when the witness is unavailable for the reasons specified in 10 U.S.G. $\S 849$ (d) (1970), and the absence is not the fault of the Armed Forces. See, e.g., United States v. Gaines, 20 U.S.C.M.A. 557, 43 C.M.R. 397 (1971). See generally McGovern, The Military Oral Deposition and Modern Communications, 45 Mr. L. Rev. 43 (1969).

112 See Dougherty \& Lynch, supra note 11, at 512-13; Lynch, supra note 11, at 154; text at notes $37-38$.

113293 F.2d 852 (D.C. Cir. 1961). Bland involved an undesirable discharge for security reasons that was based on secret evidence. The problem in the nonsecurity undesirable discharge is less serious. In the latter case, evidence is made available to the respondent, although in documentary form. E.g., Glidden v. United States, $185 \mathrm{Ct}$. Cl. 515 (1968); see Army Reg. 15-6, II 11, 16 (Aug. 12, 1966). Rebuttal by other evidence is possible, but the preferred technique of impeachment through cross-examination is not. 
relatively weak, without the protection of the right of confrontation."114 In Glidden $v$. United States, ${ }^{115}$ a serviceman was denied the opportunity to confront civilian police officers who had accused him of homosexual acts. The Court of Claims emphasized the importance of confrontation, but found it unnecessary to reach the constitutional issue because the Air Force had violated its regulations by refusing to request the civilians to appear for cross-examination. ${ }^{116}$ Glidden was approved by the same court in Cason $v$. United States, ${ }^{117}$ but the constitutional issue was avoided once again: the serviceman was denied the right to confront a locally available military witness in clear violation of the regulations. ${ }^{118}$

Only one court has suggested a contrary result. In Pickell v. Reed, ${ }^{119}$ the district court stated that, despite the lack of compulsory process to ensure opportunity for cross-examination, the regulations are "essentially fair ... and meet the requirements of due process for purposes of undesirable discharge." 120 The issue was raised, however, in the context of a predischarge attack on the facial validity of the regulations. Unlike the servicemen in the cases above, Pickell had not received a discharge. The plaintiff therefore could not allege the use of specific testimony that might have been viewed differently if crossexamination were allowed, and the court was merely holding that the plaintiff's claim of facial invalidity lacked sufficient likelihood of success on the merits to justify a preliminary injunction. ${ }^{121}$

The field board's inability to compel attendance of witnesses appears to be a problem of legislative inertia. Congress has failed to respond to Defense Department initiatives for a broader grant of subpoena powers to the discharge boards. ${ }^{122}$ The courts should not, however, allow congressional indifference to dilute the requirements of due process. There are no convincing reasons for the disparity between con-

114293 F.2d at 858.

116185 Ct. Cl. 515 (1968).

116 Id. at 521.

117471 F.2d 1225 (C.t. Cl. 1973).

118 Id. at 1231.

119326 F. Supp. 1086 (N.D. Cal. 1971).

$120 \mathrm{Id}$. at 1090 . This may be attributed to the general reluctance of courts to sustain predischarge attacks on undesirable discharges when the attacks are based on constitutional grounds. See, e.g., id.; Scofield v. United States, 297 F. Supp. 1353 (D.P.R. 1969); Unglesby v. Zimny, 250 F. Supp. 714 (N.D. Cal. 1965); Crawford v. Davis, 249 F. Supp. 943 (E.D. Pa. 1966). But cf. Covington v. Schwartz, 230 F. Supp. 249 (N.D. Cal. 1964), aff'd, 841 F.2d 537 (9th Cir. 1965). See generally Suter, supra note 54, at 73-77.

121326 F. Supp. at 1090 .

122 See H.R. 523, 92d Cong., Ist Sess. § 1161(b); 1971 Hearings, supra note 2, at 584647, 5854; Lane, supra note 3, at 112-13. 
frontational and subpoena rights in courts-martial and in "chronic offender" and "UCMJ" undesirable discharge hearings. The Armed Forces' only legitimate reason for limiting these rights is the inconvenience of transporting witnesses from far-flung stations. Although this justifies the disparity between civilian and military rights, ${ }^{123}$ there are no convincing reasons for making a distinction between the two military proceedings. ${ }^{124}$ Testimony offered without opportunity for cross-examination, therefore, must be excluded from undesirable discharge proceedings unless it falls within one of the exceptions that apply to courts-martial, ${ }^{125}$ and the discharge boards must be granted the same subpoena powers as the military courts.

\section{B. Standard of Proof}

In re Winship ${ }^{126}$ held what had long been assumed: that proof beyond a reasonable doubt is an essential element of due process in criminal proceedings. As Justice Harlan said in his concurrence:

In a criminal case, on the other hand, we do not view the social disutility of convicting an innocent man as equivalent to the disutility of acquitting someone who is guilty. ... [We] view the requirement of proof beyond a reasonable doubt in a criminal case as bottomed on a fundamental value determination of our society that it is far worse to convict an innocent man than to let a guilty man go free. ${ }^{127}$

The current Armed Services regulations make few references to the standard of proof for a recommendation of undesirable discharge. The Marine Corps requires a preponderance of the evidence; ${ }^{128}$ the Army is satisfied with "such evidence as reasonable men can accept as adequate to support a conclusion." 129

The possible harm from error, although perhaps not as great as in civilian criminal or juvenile cases, clearly outweighs the services' interest in these standards of proof. If the board errs against the service-

123 See note 111 supra.

124 The only reason expressed by military officials for the present lack of subpoena power is the time and expense of its potentially excessive use. 1966 Hearings, supra note 41, at 389-90. The then Judge Advocate General of the Army admitted, however, that this problem could easily be overcome by using the same restrictions on the number of witnesses as are applied in courts-martial. Id. at 390; see note 111 supra.

125 See note 111 supra.

128397 U.S. 358 (1970).

127 Id. at 372.

12832 C.F.R. \& 730.73(c)(20) (1972).

129 Army Reg. 15-6, I 20 (Aug. 12, 1966). The Air Force requires "evidence of sufficient weight to be convincing." 32 C.F.R. $\$ 866.9$ (1972). The Navy regulations articulate no standard of proof. 
man, he may bear the stigma of an undesirable discharge. If it errs in his favor, he may still be separated under honorable conditions by the discharge authority. ${ }^{130}$ The only loss to the service in the latter case is some small increment of deterrence. It is necessary, however, to consider separately the standards of proof appropriate for "UCMJ" and for "chronic offender" discharges. ${ }^{131}$

1. Standard of Proof for Acts Considered Crimes Under the UCMJ. In the case of the serviceman accused of drug, sex, or other criminal offenses, the discharge board performs the same function as a courtmartial and imposes essentially the same penalty. The undesirable discharge is used as an alternative to court-martial, a practice uniformly condemned by the courts that have alluded to it..132

The individual's interest in protection from factual errors is no less when he is processed administratively. In theory, a special court-martial can impose six months' imprisonment as well as a bad-conduct discharge. In practice, the services discharge-rather than imprisondrug users ${ }^{133}$ and nonviolent homosexuals ${ }^{134}$ as soon as possible if rehabilitation is unwarranted. Although imprisonment may be perceived as a greater immediate harm, the serviceman's major interest is in avoiding the long-term effect of an other than honorable discharge. ${ }^{135}$

130 See, e.g., Birt v. United States, 180 Ct. Cl. 910 (1967).

131 Undesirable discharge proceedings based on civilian conviction present little problem of proof. See note 108 supra.

132 Birt v. United States, 180 Ct. Cl. 910 (1967); Clackum v. United States, 296 F.2d 226 (Ct. Cl. 1961); United States v. Phipps, 12 U.S.C.M.A. 14, 30 C.M.R. 14 (1960) (Quinn, C.J., concurring); cf. Rowe v. United States, $167 \mathrm{Ct}$. Cl. 468 (1964). The Court of Claims has observed that the commander's power to choose between court-martial and administrative action is "as if a prosecuting attorney were authorized, in a case where he concluded that he didn't have enough evidence to obtain a conviction in court, to himself impose the fine or imprisonment which he thought the accused person deserved." Clackum v. United States, supra, at 228. The regulations allow the undesirable discharge to be awarded in lieu of court-martial if the discharge authority considers it in the best interest of the service and the individual. See the Army and Air Force regulations summarized in 1966 Hearings, supra note 41 , at 776, 781. For some examples of "the best interests of the service," see text and notes at notes 93-96 supra. There is no statutory right to demand court-martial instead of undesirable discharge. Rowe held that the enacting statute for the UCMJ preserved the then existing authority to issue administrative discharges under other than honorable conditions. $167 \mathrm{Ct}$. Cl. at 470-72; see Act of May 5, 1950, Art. 140, $\$ 5,64$ Stat. 107,$145 ; 41$ Stat. 809. No case has decided whether there is a constitutional right to demand court-martial. The confusion of "administrative" and "judicial" labels can be best avoided, though, by attacking an undesirable discharge imposed after a timely demand for court-martial as a denial of specific elements of due process-for example, proof beyond reasonable doubt. Cf. In re Gault, 387 U.S. 1 (1967).

133 See 32 C.F.R. $\$ \$ 62.1-4$ (1972) (classification of and policy towards drug users).

134 See 1966 Hearings, supra note 41 , at 778, 780 (classification of and policy towards homosexuals).

135 E.g., "You do not find a fellow very, very often asking for a court-martial instead of 
Perhaps in recognition of this, the UCMJ requires more procedural protection for punitive discharge by court-martial than for imprisonment. ${ }^{136}$ The undesirable discharge is so nearly identical to the badconduct discharge that the serviceman's interest in avoiding it is the same. Without the special discretionary problem of the chronic offender, the military interest in imposing a punitive discharge is no greater in administrative cases than in court-martial cases. Due process therefore requires proof beyond a reasonable doubt in "UCMJ" undesirable discharge cases.

2. Standard of Proof for "Frequent and Discreditable Involvement." Proceedings involving chronic military offenders are inherently errorprone. ${ }^{137}$ None of the services set clear standards; the discharge board is expected to know a chronic military offender when it sees one. ${ }^{138}$ Proof beyond reaŝonable doubt, however, may be too demanding. The Armed Forces must be able to deter potential chronic offenders by use of the undesirable discharge, and can be expected to abandon reluctantly personnel whose training represents a substantial investment. Whether a particular individual has future military worth is a decision that depends on the technical expertise of the board. "Moral certainty," 139 as the military characterizes proof beyond reasonable doubt, would greatly restrict the exercise of the discharge board's judgment.

The courts have not considered this question, The standard of proof required in deportation hearings, however, suggests a possible solution. Although a deportation hearing is not a criminal proceeding, ${ }^{140}$ it imposes a substantial personal hardship. In Woodby $v$. Immigration and Naturalization Service, the Supreme Court held that the hardship of

administrative action, because when he asks for a court-martial, he visualizes himself sitting in jail or something like that, and this he does not want." 1962 Hearings, supra note 4, at 139 (Brigadier General Kuhfeld); cf. 1966 Hearings, supra note 41, at 377. However, a man may be convicted once by a special court-martial, serve a six-month sentence, and still earn a discharge under honorable conditions. Army Reg. 635-200, II 1-7d(2), I-7e (June 12, 1968); cf. 32 G.F.R. § 730.52(a)(1) (1972) (Marine Corps).

136 A special court-martial that imposes a bad-conduct discharge must include a military judge and general court-martial qualified counsel, and it must keep a verbatim record to facilitate review. These features are not necessary if the court-martial imposes its maximum authorized sentence of six months imprisonment. 10 U.S.C. \& 819 (1970).

137 See text at notes 75-83 supra.

138 "I do not think I can give yau a rule of thumb in terms of how many offenses. I suggest that the chronic military offender . . . is the sort of individual that every company commander understands exactly of whom you speak [sic]." 1962 Hearings, supra note 4 , at 22 (Assistant Secretary of Defense for Manpower Runge); cf. 32 C.F.R. $\$ 730.66(\mathrm{~b})$ (1972) (Marine Corps), quoted at note 149 infra.

$139 \mathrm{MCM}$, supra note 21, ๆ $74 \mathrm{a}(3)$, at $13-4$.

140 Harisiades v. Shaughnessey, 342 U.S. 580 (1952). 
deportation required proof by "clear, unequivocal, and convincing evidence," 141 a standard between preponderance and reasonable doubt. Although what is clear, unequivocal, and convincing is no more quantifiable than what is a preponderance of the evidence, it expresses a greater sense of certainty than that required in a negligence case. ${ }^{142}$ It is used in civil litigation when issues of reputation-such as fraud, adultery, and bastardy-are contested. ${ }^{143}$ Requiring proof by clear, unequivocal, and convincing evidence would retain the discharge board's discretion, yet provide greater protection to the serviceman than a "preponderance" standard.

\section{The Vagueness of "Frequent and Discreditable Involvement"144}

In Avrech v. Secretary of the Navy, ${ }^{145}$ the Court of Appeals for the District of Columbia Circuit held that Article 134 of the UCMJ, the General Article, was unconstitutionally vague on its face. The relevant portion of the statute provides:

Though not specifically mentioned in this chapter, all disorders and neglects to the prejudice of good order and discipline in the armed forces, all conduct of a nature to bring discredit upon the armed forces ... shall be taken cognizance of by a . . . court-martial ... and shall be punished at the discretion of that court. ${ }^{146}$

Article 134 has been elucidated by numerous decisions of the Court of Military Appeals and over seventy specifications in the Manual for Courts-Martial; ${ }^{\mathbf{1 4 7}}$ nevertheless, the court in Avrech held it did not "provide an ascertainable standard of guilt."148

141385 U.S. 276,285 (1966).

$142 I d$.

$1439 \mathrm{~J}$. WIGMORE, EvIDENCE $\$ 2498$, at $329-34$ (3d ed. 1940). The Court of Appeals for the District of Columbia Circuit now also requires clear, unequivocal, and convincing proof in civil commitments for mental illness because of the magnitude of the injury involved. The court pointed out that the higher standard of proof would offset the speculative nature of the evidence in that type of proceeding. In re Ballay, 482 F.2d 648 (D.C. Cir. 1973).

144 Vagueness of the grounds for the "UCMJ" undesirable discharge is a less serious problem. To the extent that the conduct described in the text at notes 21-25 supra does constitute crimes under the UCMJ, the definiteness of the grounds for discharge is derived from the definiteness of the punitive articles of the Code. It has been argued by the Armed Forces, however, that the grounds for undesirable discharge may include conduct not prohibited by the UCMJ and not otherwise defined. See 1966 Hearings, supra note 41 , at 367-72. If that is the case, the vagueness argument set forth below is applicable.

145477 F.2d 1237 (D.C. Cir. 1973), prob. juris. noted, 42 U.S.L.W. 3194 (U.S. Oct. 9, 1973). 14610 U.S.C. \& 934 (1970).

147 See 477 F.2d at 1240; MCM, supra note 21, Appendix 6c, at A6-20-26.

148477 F 2d at 1241; accord, Levy v. Parker, 478 F.2d 772, 796 (3d Cir. 1973) (Article 133 of the UCMJ, penalizing conduct "unbecoming an officer and a gentleman," held 
The regulation authorizing undesirable discharge for "frequent involvement of a discreditable nature with military or civilian authorities" has never been judicially construed or administratively narrowed. ${ }^{149}$ An undesirable discharge on that ground thus raises the voidfor-vagueness issue. A penal statute is void on its face as a denial of due process if it is unnecessarily vague. ${ }^{150}$ The vagueness doctrine ensures that the citizen receives sufficient notice of the law's demands, ${ }^{161}$ and prevents enforcement officers from engaging in harassment unrelated to legitimate prohibitions on conduct. ${ }^{152}$ The vagueness doctrine applies to military as well as civilian offenses, except where it is shown that conditions peculiar to military life require a different rule. ${ }^{163}$

The vagueness standard applies not only to statutes, but also to rules made under statutory authority that have the force of law. ${ }^{164}$ Such rules must be promulgated by the proper procedure under statutory authority, and they must be reasonable. ${ }^{155}$ The military regulations

unconstitutionally vague); cf. Stolte v. Laird, 353 F. Supp. 1392 (D.D.C. 1972) (specification under Article 134 forbidding "disloyal statements" held unconstitutionally vague).

149 On the contrary, the Marine Corps states that "no specific number of acts or omissions are contemplated herein. Each case must be evaluated in light of its own particular facts to determine whether ... the member concerned has clearly demonstrated that he is unqualified for retention and, if so, whether the character of his service has been other than honorable." 32 C.F.R. $\$ 730.66(\mathrm{~b})(2)$ (1972).

150 See, e.g., Grayned v. City of Rockford, 408 U.S. 104, $108-09$ (1972) (dictum); Papachristou v. City of Jacksonville, 405 U.S. 156, 162 (1972). See generally Comment, The Void for Vagueness Doctrine in the Supreme Court, 109 U. PA. L. REV. 67 (1960). The undesirable discharge is essentially penal in both intent and effect. See text and notes at notes 61-74 and 86-96 supra.

151 See, e.g., Papachristou v. City of Jacksonville, 405 U.S. 156, 162-67 (1972) and cases cited therein.

152 See, e.g., id. at 168-71; Levy v. Parker, 478 F.2d 772, 793 (1973).

153 Avrech v. Secretary of the Navy, 477 F.2d 1237, 1244 (D.C. Cir. 1973); Kauffman v. Secretary of the Air Force, 415 F.2d 991, 997 (D.C. Cir. 1969); cf. Levy v. Parker, 478 F.2d 772, 795-96 (3d Cir. 1973).

154 Stolte v. Laird, 353 F. Supp. 1392 (D.D.C. 1972) held that certain specifications in the MCM that interpreted Article 134 of the UCMJ were void for vagueness. A "specification" is a description of the "specific facts and circumstances constituting a violation." MCM, supra note 21, ๆ 24a, at 6-1. Until Avrech v. Secretary of the Navy, 477 F.2d 1237 (D.C. Cir. 1973) was decided, the specifications in the MCM were considered sufficient to save Article 134 from being void for vagueness. United States v. Frantz, 2 U.S.C.M.A. 161, 7 C.M.R. 37 (1953).

The courts do not substitute their judgment for that of the Armed Forces in deciding whether an individual or class should be discharged from the military. See, e.g., Hagopian v. Knowlton, 470 F.2d 201, 204 (2d Cir. 1972); cf. Note, Judicial Review and Military Discipline, 72 Colum. L. Rxv. 1048, 1054-56 (1972). It is, however, within their recognized power to require the Armed Forces to provide intelligible standards in their regulations. Cf. Hagopian v. Knowlton, supra (West Point cadet entitled to notice and hearing before he can be dismissed for excess demerits).

155 Congress cannot grant the power to do what it may not do itself, including the passage of unconstitutionally vague legislation. See 1 K.C. DAvis, supra note 53, § 5.03, at 299 (1958). 
concerning undesirable discharge are promulgated under express statutory authority, and bind the serviceman and the Armed Forces. ${ }^{158}$ Except where military necessity is shown, the regulations must contain an ascertainable standard of guilt enabling a serviceman of common understanding to know what the Armed Forces forbid or command on pain of undesirable discharge. ${ }^{157}$

The standard of conduct provided in the regulation seems incurably vague. "Frequent" and "discreditable" are not defined, and the administrative review boards do not publish opinions. Military witnesses before the Ervin Subcommittee considered the term "chronic" -as used in "chronic military offender"-unquantifiable. ${ }^{158}$ The only standard for defining "frequent and discreditable" is "the individual morality of the convening authority and the three officers sitting on the administrative discharge board ...."I59

Undesirable discharge on this ground does require repeated disciplinary involvement: "frequent" must mean at least two. Moreover, before the serviceman can be given the discharge, he must be warned personally that continued misbehavior could result in such a discharge, and be given an opportunity to reform. ${ }^{160}$ These minimal forms of notice, however, do not satisfy the requirements of due process. ${ }^{101}$ The serviceman cannot predict what will trigger a warning, and afterward he is left to speculate on what will be deemed "continued" misbehavior.

The diffuse language of the regulation also invites grossly uneven application. The Armed Forces must have discretion to characterize offenders as "chronic"; but that discretion can be structured. ${ }^{162}$ If the different needs of an infantry battalion, an aircraft carrier, and a com-

15610 U.S.C. § 1169 (1970); see Murray v. United States, 154 Ct. Cl. 185 (1961); cf. Service v. Dulles, 354 U.S. 363 (1957).

157 See Papachristou v. City of Jacksonville, 405 U.S. 156, 163 (1972).

158 See note 138 supra.

159 Lynch, supra note 11 , at 150.

10032 C.F.R. \& 41.4(a)(1) (1972); Army Reg. 635-212, I 7 (July 15, 1966); 32 C.F.R. \$ 730.12(c) (1972) (Navy). There is, however, no requirement that any particular form of advice or period for rehabilitation be provided; the Army prefers to rely on the judgment of the "ordinary sensible commander." 1962 Hearings, supra note 4, at 107. The Army also provides for a second chance by transferring the individual to a different unit. Army Reg. 635-212, change no. 11, $17 \mathrm{~b}(2)$, (March 1, 1971).

101 Avrech v. Secretary of the Navy, 477 F.2d 1237, 1243 (D.C. Cir.), prob. juris noted, 94 S. Ct. 64 (1973).

162 Discretion is confined when the scope of discretionary power is limited from outside. In this area, the prime example is the limitation of the basis for undesirable discharge to incidents occurring during the individual's current enlistment. Harmon v. Brucker, 355 U.S. 579 (1958); 32 C.F.R. \& 41.4(b) (1972). "Structuring" is the guidance of subordinate administrators by their superiors on how legitimate discretionary authority should be exercised. See, e.g., note 164 infra. See generally K.C. Davis, Discretionary Justice 54-59, 102-04 (1971). 
munications center, for example, make general definitions difficult to formulate, the Secretary could issue a general directive to be made more specific by each discharge authority. The directive would specify minimum criteria for undesirable dicharge on chronic offender grounds in the following areas: which offenses are discreditable, and how they are to be weighted; the number of such offenses, nonjudicial or court-martial, required before warning the serviceman and before discharge; intelligence and proficiency test scores below which inability to comply with military discipline will be presumed and a general discharge issued; other mitigating circumstances to be considered by the discharge board. Defining such standards is within the competence of the Armed Forces. The Navy and Marine Corps have similar standards for the award of honorable discharges, ${ }^{163}$ and all the services use similar classifications for processing homosexuality cases. ${ }^{164}$ The standards need not be protective, but they must be ascertainable. ${ }^{165}$

\section{CoNGLUSTON}

The Armed Forces have strong interests in separating those individuals who will not conform to the military way of life, and in deterring others from such conduct. Undesirable, bad-conduct, and dishonorable discharges therefore have a place in the military personnel system. Nevertheless they are serious sanctions that deprive the serviceman of important benefits and opportunities, and their imposition must be accompanied by procedural protections. The serviceman must be given intelligible standards of behavior and an opportunity to meet them, and the rights necessary to contest fully the basis for the discharge action. The present regulations governing undesirable discharges fall far short of these requirements. The soldier accused of failing to meet his obligation of honorable service and threatened with undesirable

16332 C.F.R. $\$ \$ 730.2$ (Navy), 730.52 (Marine Corps) (1972).

164 See 1966 Hearings, supra note 41, at 778, 780.

165 Frequent and discreditable involvement does not raise-at least facially-first amendment questions. Overbreadth, therefore, is not an issue. Cf. Levy v. Parker, 478 F.2d 772, 793-94 (3d Cir. 1973); Stolte v. Laird, 353 F. Supp. 1392, 1401-05 (D.D.C. 1972). The vagueness problem is cured if the standard for frequent and discreditable involvement is sufficiently knowable to provide an ascertainable standard of guilt and limit arbitrary enforcement. See text and notes at notes 151-52 supra.

Classifying Article 15 punishment as a discreditable involvement leaves open the possibility of arbitrary action. Nonjudicial punishment, however, is necessary for low-level discipline. See text and note at note 92 supra. Abuses of nonjudicial punishment may be confined with the least harm to legitimate military needs by providing for cross-examination of the serviceman's superiors, a higher standard of proof, and administrative clarification of the number and type of nonjudicial punishments constituting grounds for undesirable discharge. 
discharge must be allowed the same rights of confrontation and subpoena accorded those who face similar penalties in more formal proceedings. The proof required for undesirable discharge must be commensurate with the seriousness of the sanction, qualified only by the overriding administrative imperatives and considerations of deterrence present in chronic offender cases. The regulations also must give the serviceman adequate notice of the actions that may be grounds for undesirable discharge. ${ }^{106}$

The Armed Forces' interests are adequately protected by this interpretation of the due process requirements for undesirable discharge. Procedures for discharging a serviceman convicted by a civilian court in a fair trial-the clearest candidates for undesirable dischargewould be unaffected. The chronic military offender could still be separated from the service with little reduction in deterrent effect and only minor inconvenience to the Armed Forces. Servicemen who commit acts punishable as crimes under the UCMJ could still be punished either by court-martial or by an administrative proceeding only moderately more burdensome to the Armed Forces than the present practice. Due process requires these minor sacrifices.

James M. Hirschhorn

106 If the courts require these procedural protections in undesirable discharge hearings, the Armed Forces can provide all except the subpoena power by amending their regulations. The Armed Forces consider the extension of the subpoena power to discharge boards to be beyond their statutory authority, however, see 1962 Hearings, supra note 4, at 117, and congressional action would be necessary to create that power. The Department of Defense has sponsored legislation to authorize subpoenas by administrative discharge boards. See note 122 supra. 